\title{
Biocidal Activity and Corrosion Inhibition of Some Cationic Surfactants Derived from Thiol Polyurethane
}

\author{
Mohamed. F. Zaky ${ }^{1}$, I. A. Sabbah'², N.A. Negm ${ }^{1}$, M. E. Hendawy ${ }^{2 *}$ \\ ${ }^{1}$ Petrochemicals Department, Egyptian Petroleum Research Institute, Cairo, Egypt. \\ ${ }^{2}$ Faculty of Science, Al-Azhar University, Cairo, Egypt.
}

\begin{abstract}
NIX series of cationic polyurethane surfactants [PQ10-20] were synthesized by the reaction $\checkmark$ between different six esters (which prepared by condensation of fatty alcohols namely: octanol, decanol, dodecanol, tetradecanol, hexadecanol and octadecanol with bromoacetic acid) and polyurethane as quaternizing agent. The chemical structures of these surfactants were confirmed using elemental analysis, FTIR spectra, ${ }^{+} \mathrm{HNMR}$ and UV analysis. The surface activities of the synthesized cationic thiol polyurethane surfactants showed their tendency towards adsorption at the air/water interface. The adsorption tendency was estimated from the values of surface tension and the depression of surface tension at the critical micelle concentration. The studied surfactants were evaluated as antimicrobial agents against pathogenic and sulfur reducing bacteria using inhibition zone diameters and minimum inhibition concentration values. The synthesized cationic thiol polyurethane surfactants showed good antimicrobial activities against the tested microorganisms including Gram positive, Gram negative as well as fungi. The synthesized compounds were tested for the activity as corrosion inhibitors against carbon steel corrosion in $2 \mathrm{~N} \mathrm{H}_{2} \mathrm{SO}_{4}$ at 50,100, 200, 400 and $600 \mathrm{ppm}$. The inhibition efficiencies of the tested compounds showed good inhibition and protection of the carbon steel. The corrosion inhibition tendency correlated to the surface activity and chemical structure of the compounds.
\end{abstract}

Keywords: Cationic surfactants, Surface activity, Adsorption , Antimicrobial activity, Corrosion inhibition, Polyurethane.

\section{Intoduction}

Corrosion inhibitors are added to prevent metal dissolution during its surface cleaning from oxides and other adherent materials [1]. Also, corrosion inhibitors may be liquids or powder form that effectively reduces the corrosion rate by adsorbing on the metal surface $[2,3]$. Corrosion inhibition efficiency of organic compounds is related to their adsorption properties [4]. Corrosion protection of steel in acidic media is of great importance for both industrial facilities and theoretical aspects [5]. The adsorption of these molecules depends mainly on certain physicochemical properties of the inhibitor molecule such as the presence of heteroatoms including: oxygen, sulfur, nitrogen atoms and multiple bonds in the molecule through which they are adsorbed on the metal surface [6-10].

Heteroatoms such as nitrogen, oxygen, and sulfur are capable of forming coordinate covalent bond with metal owing to their free electron pairs and thus acting as inhibitor. Compounds with $\pi$ bonds generally exhibit good inhibitive properties due to the interaction of $\pi$ orbital with metal surface [11-13]. The selection of a suitable inhibitor for a particular system is a difficult task because of the selectivity of the inhibitors and wide variety of corrosive environment. As a result, several types of corrosion inhibitors were developed to fit the different types of corrosion processes and also the medium where the corrosion takes place. Corrosion inhibition of carbon steel in sulfuric

*Corresponding author e-mail: mostafaeid97@yahoo.com

DOI: 10.21608/EJCHEM.2017.2119.1169

C2017 National Information and Documentation Centre (NIDOC) 
acid was studied using some cationic surfactants derived from Thiol polyurethane with different molecular structures [14-16].

On the other hand, to overcome the alarming problem of microbial resistance to antibiotics, the discovery of novel active compounds against new targets is a matter of urgency. Many of the crude drugs, which are sources of medicinal preparations, still originate from wild growing material. However, plant-based drugs have shortened the life span of the source of material. There is a continuous search for more potent and cheaper raw materials to feed the industry. Cationic surfactants are organic compounds with great utility in important fields such as medicine, agriculture and cosmetic products [17]. Some cationic surfactants present anticancer, antitumor and antibacterial activity [18].

In this study, six new cationic Thiol polyurethane surfactants were synthesized, characterized and evaluated as corrosion inhibitors against the corrosion of carbon steel in acidic media and also as antibacterial agents to prevent bacterial growth. The relation between the surface activity and the efficiency of these compounds in the different applications was discussed.

\section{Materials and Methods}

\section{Chemicals}

Fatty alcohols (octanol, decanol, dodecanol, tetradecanol, hexadecanol and octadecanol) were purchased from Sigma (99 \%), toluene diisocyanate TDI were purchased from (DOW, 97 $\%$ ), Triethanol amine (ADWIC, $99 \%$ ), Mercapto acetic acid were purchased from (Aldrich, $98 \%$ ), Bromoacetic acid were purchased from (Aldrich, 98\%), ethyl alcohol (ADWIC, $99 \%$ ) and sulfuric acid (ADWIC, $99 \%$ ).

\section{Instrumentation}

Elemental analysis was done using Vario Elementar Analyzer; IR spectroscopy was done using Perkin Elmer FTIR System (Genesis Fourier Transformer FTIRTM) in the 4,000-400 cm-1 region using $\mathrm{KBr}$ disks; ${ }^{+} \mathrm{H}-\mathrm{NMR}$ spectroscopy was done using Varian NMR-300, Mercury 300 $\mathrm{MHz}$ spectrometers in $\mathrm{CDCl} 3$ solvent and TMS as internal standard and the chemical shifts reported in $\mathrm{d}(\mathrm{ppm})$; Ultra violet was done using Perkin-Elmer S52 spectrophotometer; Surface and interfacial tension was done using K6-Kru"ss Tensiometer with platinum ring and weights.

\section{Synthesis}

Preparation of Triethanol amine mono Mercapto acetate

Triethanol amine $(0.1$ mole $)$ reacts with mercaptoacetic acid $(0.1$ mole $)$ to form the targeted compound. The solvent used was xylene due to its high boiling point to ensure the completion of the reaction. The reaction procedure involves the addition of the reaction mixtures and suitable dehydrating agent (p-toluene sulfonic acid, $0.1 \mathrm{~g}$ ) in three necked flasks connected with efficient condenser, dean stark joint and stirrer. The completion of the reaction is indicated as the equivalent amount of water of reaction is trapped in the dean stark connection. The interaction takes about 12 hours. After removal of the solvent under vacuum using rotary evaporator, the catalyst was then removed from the reaction product by extracting them using petroleum ether. Subsequent purification was done by means of vacuum distillation to remove the excess, unreacted and residual materials to afford Triethanol amine mono Mercapto acetate, [19] yield 96\%.

\section{Preparation of the targeted Thiol polyurethane compound}

The polymerization was carried out in a four-necked round bottom flask equipped with a mechanical stirrer, and dropping funnel. An excess amount of TDI ( 0.1 mole $)$ dissolved in acetone; $(100 \mathrm{ml})$ was added to the four-neck flask and stirred. TEA ${ }_{\text {MER }}(0.2$ mole $)$ and five drops of triethylenediamine (TEDA) were dissolved in $40 \mathrm{ml}$ of acetone solution and was added slowly during $20 \mathrm{~min}$ to the TDI solution [20]. The reaction mixture was then stirred at $30{ }^{\circ} \mathrm{C}$ for 30 min to form the pre-polymer. The $\mathrm{NCO} / \mathrm{OH}$ ratio was kept 1:2 in polyurethane reaction.

\section{Preparation of the fatty alcohol ester of Bromoacetic acid \\ Bromoacetic Acid (0.1 mol.) and octanol,} decanol, dodecanol, tetradecanol, hexadecanol and octadecanol (0.1 mol.) were esterified respectively in xylene in presence of $0.01 \%$ p-toluene sulphonic acid as catalyst, the mixture was refluxed until the azeotropic amount of water $(1.8 \mathrm{~mL})$ was removed. The interaction takes about 8-16 hours according to the hydrophobic chain length (fatty alcohol). After removal of the solvent under vacuum using rotary evaporator, the catalyst was then removed from the reaction product by extracting them using petroleum ether. Subsequent purification was done by means of vacuum distillation to remove the excess and 
unreacted and residual materials [21] to afford the different fatty alcohol esters of Bromoacetic acid. The yield of the products, octyl bromoacetate (C10), decyl bromoacetate (C12), dodecyl bromoacetate (C14), tetradecyl bromoacetate (C16), hexadecyl bromoacetate (C18) and octadecyl bromoacetate(C20) esters were $95-98 \%$.

Preparation of cationic Thiol polyurethane surfactants $(P Q)$

A solution of Thiol polyurethane compound contained tertiary amine and octyl, decyl, dodecyl, tetradecyl, hexadecyl, octadecyl esters were mixed. The mixtures were refluxed in presence of dimethyl formamide (DMF) for a period ranging from 1 day to 5 days according to hydrophobic chain length. Then left to stand overnight and then filtered. The product was recrystallized three times from ethanol and dried in vacuum oven at $40^{\circ} \mathrm{C}$ to afford a brown viscous liquid (PQ10, PQ12, PQ14, PQ16, PQ18 and PQ20) yield 8289\%. [22, 23] (Scheme 1)

\section{Chemical structure}

Elemental analysis

The elemental analysis of the synthesized cationic Thiol polyurethane surfactants showed that the expected and found values of the different elements are very close to each other, indicating the purity of the synthesized compound. (Table 1)

\section{FTIR Spectroscopy}

The chemical structure of Triethanol amine mono Mercapto acetate was confirmed using FTIR as follows:-

Absorption band at $3435 \mathrm{~cm}^{-1}$ corresponding to $\mathrm{OH}$ stretching group, very weak band at $2550 \mathrm{~cm}^{-1}$ corresponding to Thiol S-H group, absorption band at $2925 \mathrm{~cm}^{-1}$ corresponding to symmetric stretching of $\mathrm{C}-\mathrm{H}$ group, band at 1018 $\mathrm{cm}-1$ corresponding to $\mathrm{C}-\mathrm{N}$ stretching group of aliphatic amine and absorption band at $1732 \mathrm{~cm}-1$ corresponding to $\mathrm{C}=\mathrm{O}$ group.

The chemical structure of the targeted Thiol polyurethane compound confirmed using FTIR as follow:

Absorption band at $(1660-1663) \mathrm{cm}^{-1}$ corresponding to $\mathrm{C}=\mathrm{O}$ in urethane group, absorption band at $(1458-1462) \mathrm{cm}-1$ corresponding to $\mathrm{N}-\mathrm{H}$ binding in urethane group, $(1508-1510) \mathrm{cm}-1$ corresponding to $\mathrm{C}=\mathrm{C}$ of aromatic ring of toluene diisocyanate moiety.

The chemical structure of fatty alcohol esters confirmed using FTIR as follow:

The IR spectra of these esters showed complete disappearance of the absorption band at $3400 \mathrm{~cm}^{-1}$ which characterizes the aliphatic hydroxyl groups of fatty alcohols and acids and the appearance of a new absorption band at (1736-
1738) $\mathrm{cm}^{-1}$ indicates the formation of the carbonyl of ester group. Absorption bond at (1275-1277) cm-1 corresponding to ether linkages -C-O-, absorption band at (2920-2922) cm-1 and (28492850) $\mathrm{cm} 1$ corresponding to methyl $(\mathrm{CH} 3)$ and methylene $(\mathrm{CH} 2)$ groups respectively. On the other hand, the characteristic band of $\mathrm{C}-\mathrm{Br}$ bond was appeared in the range of 663-667 cm-1.

The chemical structure of cationic Thiol polyurethane surfactants confirmed by using FTIR as follow

All bands which appear in FTIR spectra of fatty alcohol bromo esters and Thiol polyurethane appeared in FTIR spectra of cationic polyurethane surfactants. Two specific bands appeared at 1460 cm-1 and $2960 \mathrm{~cm}-1$ corresponding to vibration and elongation of $[\mathrm{N}+]$ group.

$H^{1} N M R$ as follows:

The $\mathrm{H}^{1} \mathrm{NMR}$ spectra of the synthesized cationic surfactants (representatively for PQ10 \& PQ14) showed the appearance of signals at:-

$\mathrm{d}=0.85 \mathrm{ppm}$ assigned to terminal methyl group of fatty alcohol (CH3).

$\mathrm{H}^{1}$ NMR also showed an increase in the integration of the signal at $1.25 \mathrm{ppm}$, which is attributed to the presence of the methylene groups of the fatty alcohols moiety $\left(\mathrm{CH}_{2}\right)_{n}$.

$\mathrm{d}=2.5 \mathrm{ppm}$ assigned to methyl group on aromatic rings (toluene diisocyanate).

Three intense signals centered at $\mathrm{d}=7.8 \mathrm{ppm}, 8.0$ ppm and $8.2 \mathrm{ppm}$ attributed to the aromatic proton.

UV spectra as follow:-

UV spectra were recorded with a PerkinElmer S52 spectrophotometer. The cationic thiol polyurethane surfactants were confirmed by the appearance of new bands in UV spectra (Table 2 ).

\section{Measurements}

Surface Tension measurements $(\gamma)$

The surface tension of the prepared surfactants was measured as a function of concentration at 25 ${ }^{\circ} \mathrm{C}$. The $\mathrm{CMC}$ and surface tension at CMC were determined. [24].

\section{Antimicrobial activity measurements \\ Microorganisms}

The biocidal activity of the synthesized surfactants was tested against different bacterial strains (ATCC: American Type Culture Collection) as follows: Staphylococcus aureus ATCC 29213, Escherichia coli ATCC 25922, Pseudomonas aeruginosa ATCC 27853, Bacillus subtilis ATCC 55422, Desulfomonas pigra ATCC 29098 and Staphylococcus typhimurium ATCC 27948.

The Sulfur Reducing Bacteria (SRB) are a Egypt. J. Chem. 61, No. 1 (2018) 

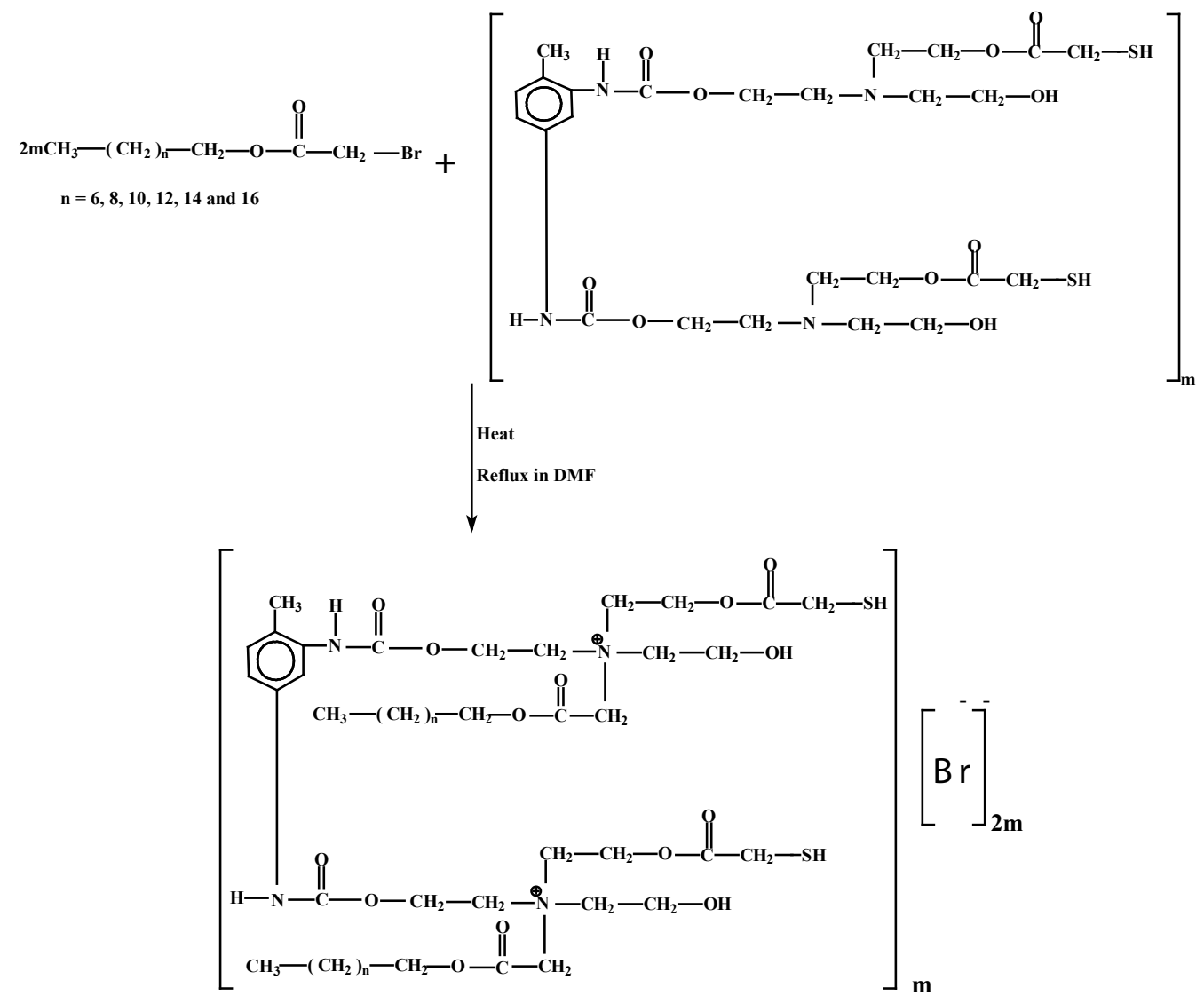

$\mathrm{m}=$ number of rebeating unit

Scheme 1. Cationic Thiol polyurethane Surfactants.

TABLE 1. Elemental analysis of the synthesized cationic Thiol polyurethane surfactants.

\begin{tabular}{|c|c|c|c|c|c|c|c|c|c|c|c|c|}
\hline \multirow[b]{3}{*}{$\mathrm{PQ}_{10}$} & \multirow{3}{*}{$\begin{array}{c}\text { M.wt } \\
20500 \mathrm{~g} / \\
\text { mole }\end{array}$} & \multirow[t]{2}{*}{ C.F. } & \multicolumn{2}{|c|}{$\mathrm{C} \%$} & \multicolumn{2}{|c|}{ H\% } & \multicolumn{2}{|c|}{ N\% } & \multicolumn{2}{|c|}{ S\% } & \multicolumn{2}{|c|}{$\mathrm{Br} \%$} \\
\hline & & & Calc. & Found & Calc. & Found & Calc. & Found & Calc. & Found & Calc. & Found \\
\hline & & $\left(\mathrm{C}_{45} \mathrm{H}_{78} \mathrm{O}_{14} \mathrm{~N}_{4} \mathrm{~S}_{2} \mathrm{Br}_{2}\right) \mathrm{n}$ & 46.47 & 46.42 & 6.65 & 6.66 & 5.56 & 5.53 & 6.35 & 6.30 & 15.89 & 15.85 \\
\hline $\mathrm{PQ}_{12}$ & $\begin{array}{c}21400 \mathrm{~g} / \\
\text { mole }\end{array}$ & $\left(\mathrm{C}_{49} \mathrm{H}_{86} \mathrm{O}_{14} \mathrm{~N}_{4} \mathrm{~S}_{2} \mathrm{Br}_{2}\right) \mathrm{n}$ & 48.54 & 48.50 & 7.05 & 7.06 & 5.27 & 5.25 & 6.02 & 5.98 & 15.05 & 15.01 \\
\hline $\mathrm{PQ}_{14}$ & $\begin{array}{c}22300 \mathrm{~g} / \\
\text { mole }\end{array}$ & $\left(\mathrm{C}_{53} \mathrm{H}_{94} \mathrm{O}_{14} \mathrm{~N}_{4} \mathrm{~S}_{2} \mathrm{Br}_{2}\right) \mathrm{n}$ & 50.36 & 50.31 & 7.41 & 7.43 & 5.00 & 4.97 & 5.71 & 5.68 & 14.28 & 14.25 \\
\hline $\mathrm{PQ}_{16}$ & $\begin{array}{c}23200 \mathrm{~g} / \\
\text { mole }\end{array}$ & $\left(\mathrm{C}_{57} \mathrm{H}_{02} \mathrm{O}_{14} \mathrm{~N}_{4} \mathrm{~S}_{2} \mathrm{Br}_{2}\right)_{\mathrm{n}}$ & 52.04 & 52.00 & 7.74 & 7.76 & 4.76 & 4.73 & 5.44 & 5.41 & 13.60 & 13.56 \\
\hline $\mathrm{PQ}_{18}$ & $\begin{array}{c}24100 \mathrm{~g} / \\
\text { mole }\end{array}$ & $\left(\mathrm{C}_{61} \mathrm{H}_{110} \mathrm{O}_{14} \mathrm{~N}_{4} \mathrm{~S}_{2} \mathrm{Br}_{2}\right)_{\mathrm{n}}$ & 53.57 & 53.54 & 8.03 & 8.05 & 4.54 & 4.51 & 5.19 & 5.17 & 12.99 & 12.96 \\
\hline $\mathrm{PQ}_{20}$ & $\begin{array}{c}25000 \mathrm{~g} / \\
\text { mole }\end{array}$ & $\left(\mathrm{C}_{65} \mathrm{H}_{118} \mathrm{O}_{14} \mathrm{~N}_{4} \mathrm{~S}_{2} \mathrm{Br}_{2}\right)_{\mathrm{n}}$ & 54.97 & 54.93 & 8.31 & 8.29 & 4.35 & 4.32 & 4.97 & 4.95 & 12.44 & 12.39 \\
\hline
\end{tabular}

Egypt. J. Chem. 61, No. 1 (2018) 
TABLE 2. UV adsorption maxima of Cationic Thiol polyurethane surfactants.

\begin{tabular}{|c|c|}
\hline Compound & $\boldsymbol{\lambda}_{\max }(\mathbf{n m})$ \\
\hline $\mathrm{PQ}_{10}$ & 208 \\
\hline $\mathrm{PQ}_{12}$ & 212 \\
\hline $\mathrm{PQ}_{14}$ & 210 \\
\hline $\mathrm{PQ}_{16}$ & 234 \\
\hline $\mathrm{PQ}_{18}$ & 216 \\
\hline $\mathrm{PQ}_{20}$ & 214 \\
\hline
\end{tabular}

common problem in the oilfield systems that should be protected. On the other hand, the selected species cause dangerous diseases for the humans and animals.

\section{Growing of microorganisms}

The bacterial strains were cultured according to the standards of the National Committee for Clinical Laboratory (NCCLS) [25]. The bacterial species grow on nutrient agar. The nutrient agar medium consisted of Beef extract $(3.0 \mathrm{~g} / \mathrm{L})$, Peptone $(5.0 \mathrm{~g} / \mathrm{L})$, Sodium chloride $(5.0 \mathrm{~g} / \mathrm{L})$, Agar $(20.0 \mathrm{~g} / \mathrm{L})$; then the volume was completed to one liter distilled water, the mixture heated until boiling and the media sterilized by autoclave. The bacterial strains were kept on nutrient agar medium and showed no inhibition zones.

Measurements of resistance and susceptibility

For preparation of discs and inoculation, $1.0 \mathrm{~mL}$ of inocula were added to $50 \mathrm{~mL}$ of agar media $\left(40{ }^{\circ} \mathrm{C}\right)$ and mixed. The agar was poured into $120 \mathrm{~mm}$ petri dishes and allowed to cool to room temperature. Wells $(6 \mathrm{~mm}$ in diameter) were cut in the agar plates using proper sterile tubes and filled up to the surface of agar with $0.1 \mathrm{~mL}$ of the synthesized cationic Thiol polyurethane surfactants (PQ10-20) dissolved in DMF $(5 \mathrm{mg} / \mathrm{mL}$ DMF $)$. The plates were left on a leveled surface, incubated for $24 \mathrm{~h}$ at $30{ }^{\circ} \mathrm{C}$ and then the diameters of the inhibition zones were read. The inhibition zone formed by these compounds against the particular test bacterial strain determined qualitatively the antibacterial activities of the synthetic compounds. The mean value obtained for three individual replicates was used to calculate the zone of growth inhibition of each sample. The antimicrobial activity was calculated as a mean of three replicates. The tested compounds were completely compatible with the medium of agar and no turbidity was observed during the mixing process $[25,26]$.

\section{Weight loss measurements}

The weight loss experiments were performed with carbon steel specimens having a composition of (wt \%): $0.21 \mathrm{C}, 0.035 \mathrm{Si}, 0.025 \mathrm{Mn}, 0.082 \mathrm{P}$ and the remainder is Fe. The carbon steel sheets of 2.5 $\mathrm{cm} * 2.0 \mathrm{~cm} * 0.6 \mathrm{~cm}$ were abraded with a series of emery papers (grade 320, 500, 800 and 1200) and then washed with acetone and distilled water. After weighing accurately, the specimens were immersed in $250 \mathrm{~mL}$ solution of $2 \mathrm{~N} \mathrm{H}_{2} \mathrm{SO}_{4}$ without and with the tested inhibitors (PQ10-20) at different concentrations (50,100, 200, 400 and 600 ppm) for 14 days. Then, the specimens were taken out, washed, dried and weighed accurately [27]. The test was performed for three specimens and the weight was the average of the three specimens. The coupons were polished by hard plastic brush, hot water then by ethanol to remove the corrosion products. The corrosion rate $(\mathrm{R})$ and the inhibition efficiency (IE \%) were calculated using Eqs. (1 and 2) [28]:

$$
\begin{array}{cl}
\mathrm{R}=\mathrm{W} / \mathrm{At} & 1 \\
\mathrm{IE} \%=\left[\left(\mathrm{R}_{0}-\mathrm{R}\right) / \mathrm{R}_{0}\right] 100 & 2
\end{array}
$$

where $\mathrm{W}$ is the average weight loss of three parallel carbon steel sheets, A is the total area of the specimen, $\mathrm{t}$ is immersion time, $\mathrm{R}_{0}$ and $\mathrm{R}$ are the values of the corrosion rate without and with addition of the inhibitor, respectively [29, 30].

\section{Results and Discussion}

\section{Surface activity}

Surface tension is a characteristic property of liquids. This phenomenon appeared originally from the attraction between the molecules at the surface. 
The surface tension value of the bidistilled water at $25^{\circ} \mathrm{C}$ was found to be $71.8 \mathrm{mN} / \mathrm{m}$ which is attributed to the attraction forces between water molecules at the water surface due to the hydrogen bonds. If there are any foreign molecules present at the water surface, this results in disturbing the tension leading to a decrease to lower values. Meanwhile surfactant molecules tend to be adsorbed at the airwater interface at lower concentrations. Hence, by increasing the surfactant concentration, the surface tension of the resulted solution generally decreased. Figures $1 \& 2$ show the relation between the surface tension values in $(\mathrm{mN} / \mathrm{m})$ and the concentration $(\log \mathrm{C})$ at $25^{\circ} \mathrm{C}$. These curves are characterized by two regions, one at lower concentration which is very sensitive towards the concentration reaction; the other surface tension curves are almost constant with variation of the surfactant concentration. Extrapolation of these two regions determines the so-called critical micelle concentration CMC. [31].

The critical micelle concentration is defined as the concentration of the surfactant at which no further decrease in the surface tension could be obtained upon addition of any further amounts of surfactant in the solution. There is an equilibrium between the singly adsorbed surfactant molecules at the interface and the micellized surfactant molecules. That equilibrium occurred at the concentration of complete surface tension (CMC) $[32,33]$. The micelle formation is the most vital point of view in the surfactant fundamental, because it is the most effective geometrical arrangement of the molecules at the desired concentrations of the synthesized surfactants given from their surface tension isotherms as listed in (Table 3).

Obviously, the CMC values are dependent on the chemical structure of the surfactant molecules [34]. The different CMC values of this surfactant depend on the hydrophobic moieties in its structure. Increasing the hydrophobic chain length, the number of repeated methylene groups $(\mathrm{CH} 2)$ decreases the $\mathrm{CMC}$ values. That effect could be explained by the view of the hydrophobicity of the surfactant molecules. Increasing the hydrophobic chain length of the surfactant molecules increases their nonpolar characters, which result in increasing the repulsion forces between them and the polar water molecules (thermodynamically unstable). Hence, the molecules tend to reduce this unfavorable situation by forming more stable aggregative structures which are micelles (thermodynamically stable). Therefore the $\mathrm{CMC}$ was at a lower concentration [35].

\section{Antimicrobial activity}

In this work we aim to evaluate the prepared cationic surfactants as biocide against some pathogenic Gram-positive bacteria (Bacillus subtilis, Staphylococcus aureus), Gramnegative bacteria (Salmonella typhimurium and Escherichia coli) and some pathogenic fungi (Candida albicans and Aspergillus niger).

The results of antimicrobial activity are recorded in Table 4, indicating that the synthesized compounds have antimicrobial activity range from a moderate to high effect on Gram negative bacteria, Gram positive bacteria, yeast and weak effect on fungi compared to the drug reference used. Where the inhibition zone for Bacillus subtilis ranges from $15-27 \mathrm{~mm} / \mathrm{mg}$ compared to $26 \mathrm{~mm} / \mathrm{mg}$ for Chloramphencol drug, for Staphylococcus aureus, it ranges from 0-22 mm/ $\mathrm{mg}$ compared to $25 \mathrm{~mm} / \mathrm{mg}$ for Chloramphencol drug, for Salmonella typhimurium ranges from $0-15 \mathrm{~mm} / \mathrm{mg}$ compared to $28 \mathrm{~mm} / \mathrm{mg}$ for Cephalothin drug, for Escherichia coli ranges from $10-26 \mathrm{~mm} / \mathrm{mg}$ compared to $27 \mathrm{~mm} / \mathrm{mg}$ for Cephalothin drug, for Candida albicans ranges from $17-27 \mathrm{~mm} / \mathrm{mg}$ compared to $28 \mathrm{~mm} / \mathrm{mg}$ for cycloheximide drug, for Penicillium chrysogenum ranges from $0-13 \mathrm{~mm} / \mathrm{mg}$ compared to $26 \mathrm{~mm} /$ $\mathrm{mg}$ for cycloheximide drug.

The biological activities of surfactants often show a non-linear dependence on their chain length, where bactericide and fungicide activities increase by increasing hydrophobic chain length.

Data in Table 4 reveal that the synthesized surfactants have antimicrobial activities, and the difference in their activities depends on the length of hydrophobic chains of prepared surfactants. The optimal length of alkyl chain has been noted to be 10 carbon atoms, which exhibit the maximum inhibition zone (PQ10). These results are in agreement with results obtained previously, which indicates that the optimal activity toward a variety of bacterial species for numerous structural variations of water soluble surfactants occurs with an alkyl chain between 10 and 14 carbon atoms. These results are in agreement with those reported elsewhere [36-39].

The biological activities of the synthesized cationic Thiol polyurethane surfactants were generally decreased by increasing the hydrophobic chain length.

This could be referred to the adsorption ability of the surfactants containing long chains 
TABLE 3. Surface properties of the synthesized cationic Thiol polyurethane surfactants in bidistilled water at $25^{\circ} \mathrm{C}$.

\begin{tabular}{|c|c|c|c|c|c|c|}
\hline Compound & $\begin{array}{c}\text { CMC, Mole/L } \\
\left(\times 10^{-6}\right)\end{array}$ & $\underset{\mathrm{mN} / \mathbf{m}}{\gamma_{\mathrm{cmc}}}$ & $\begin{array}{c}\pi_{\mathrm{cmc},} \\
\mathrm{mN} / \mathbf{m}\end{array}$ & $\begin{array}{c}T_{\max }, X 10^{-11} \\
\text { Mol.K } K^{-1} \mathrm{~cm}^{-1}\end{array}$ & $\begin{array}{l}\mathbf{A}_{\min }, \\
\mathbf{n m}^{2}\end{array}$ & 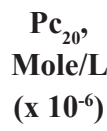 \\
\hline $\mathrm{PQ}_{10}$ & 12.6 & 40 & 31.8 & 10.8 & 15.2 & 1.58 \\
\hline $\mathrm{PQ}_{12}$ & 10 & 35 & 36.8 & 10.2 & 16.2 & 15.8 \\
\hline $\mathrm{PQ}_{14}$ & 3.1 & 35 & 36.8 & 7.9 & 20.9 & 158 \\
\hline $\mathrm{PQ}_{16}$ & 12.5 & 37 & 34.8 & 18.5 & 8.9 & 11.2 \\
\hline $\mathrm{PQ}_{18}$ & 7.9 & 40.5 & 31.3 & 16.3 & 9.9 & 11.2 \\
\hline $\mathrm{PQ}_{20}$ & 6.3 & 43 & 28.8 & 15.2 & 10.8 & 8.9 \\
\hline
\end{tabular}

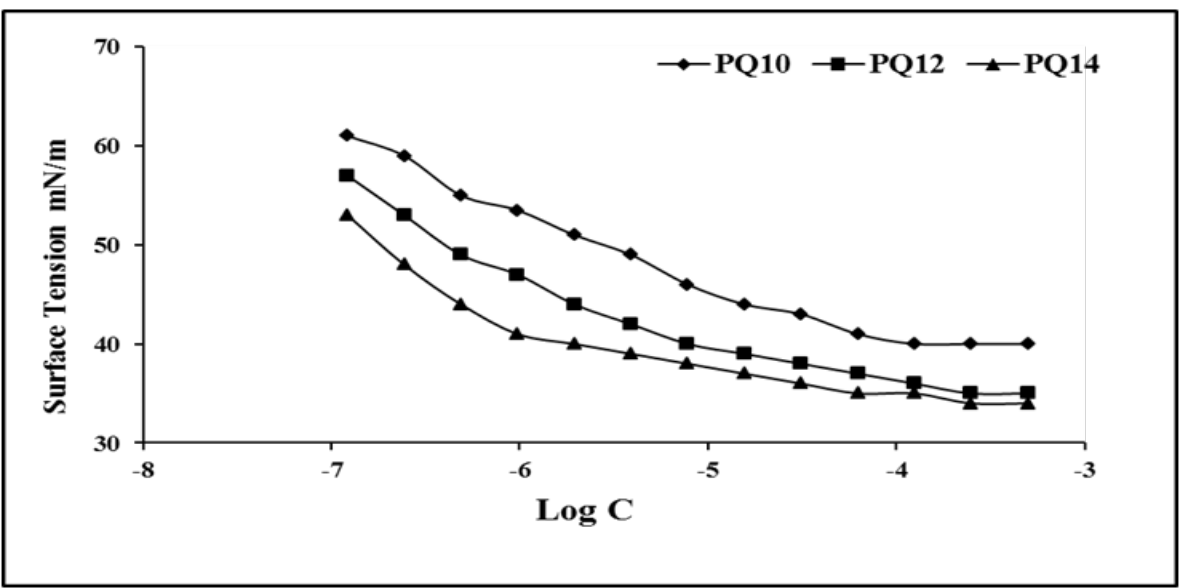

Fig. 1. Surface tension vs. $\log$ concentration profile of the synthesized cationic Thiol polyurethane surfactants ( $\mathrm{PQ10}$, $\mathrm{PQ12,} \triangle \mathrm{PQ14})$ at $25^{\circ} \mathrm{C}$.

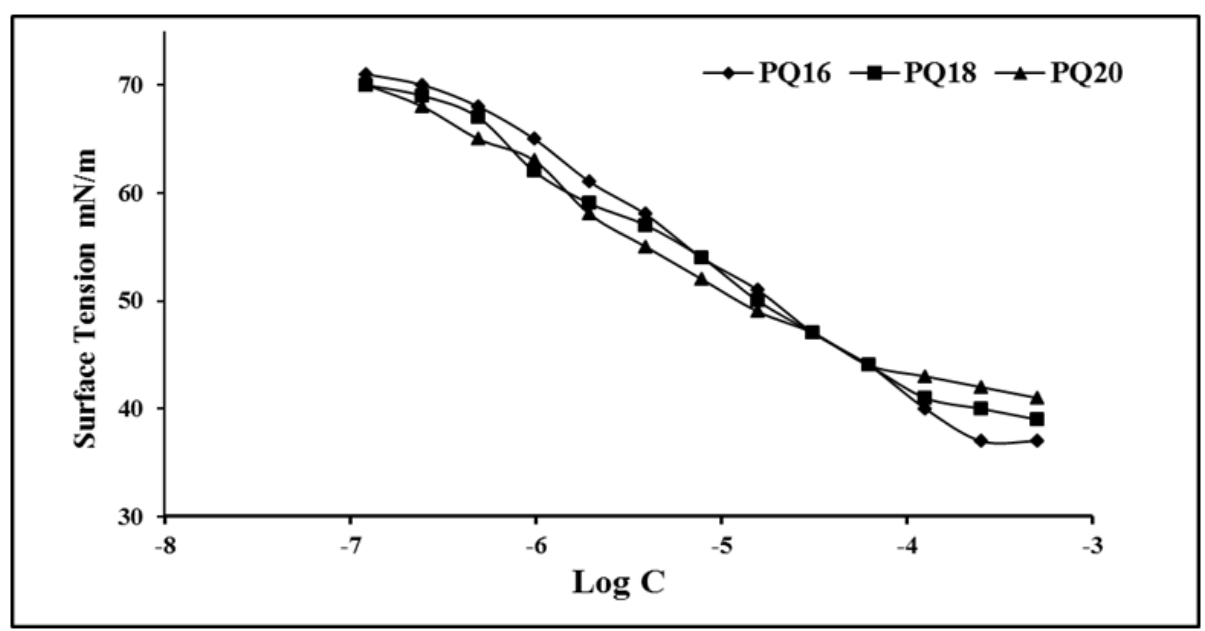

Fig. 2. Surface tension vs. $\log$ concentration profile of the synthesized cationic Thiol polyurethane surfactants( $\bullet$ $P Q 16,-P Q 18, \triangle P Q 20)$ at $25^{\circ} \mathrm{C}$. 
TABLE 4. Antimicrobial activity of synthesized surfactants against pathogenic bacteria, yeast and fungi.

\begin{tabular}{|c|c|c|c|c|c|c|}
\hline \multirow{3}{*}{ 曾 } & \multicolumn{4}{|c|}{ Bacteria } & \multirow{3}{*}{$\begin{array}{c}\text { Yeast } \\
\begin{array}{c}\text { Candida } \\
\text { albicans }\end{array}\end{array}$} & \multirow{3}{*}{$\begin{array}{c}\text { Fungi } \\
\begin{array}{c}\text { Aspergillus } \\
\text { niger }\end{array}\end{array}$} \\
\hline & \multicolumn{2}{|c|}{ Gram positive } & \multicolumn{2}{|c|}{ Gram negative } & & \\
\hline & $\begin{array}{l}\text { Bacillus } \\
\text { subtilis }\end{array}$ & $\begin{array}{l}\text { Staphylococcus } \\
\text { aureus }\end{array}$ & $\begin{array}{l}\text { Salmonella } \\
\text { typhimurium }\end{array}$ & $\begin{array}{l}\text { Escherichia } \\
\text { coli }\end{array}$ & & \\
\hline Control & 26 & 25 & 28 & 27 & 28 & 26 \\
\hline $\mathrm{PQ}_{10}$ & 27 & 22 & 15 & 26 & 26 & 0 \\
\hline $\mathbf{P Q}_{12}$ & 17 & 20 & 13 & 16 & 25 & 12 \\
\hline $\mathbf{P Q}_{14}$ & 15 & 16 & 10 & 14 & 24 & 13 \\
\hline$P_{16}$ & 23 & 14 & 0 & 10 & 17 & 0 \\
\hline $\mathbf{P Q}_{18}$ & 25 & 9 & 0 & 23 & 19 & 0 \\
\hline $\mathbf{P Q}_{20}$ & 22 & 0 & 0 & 21 & 27 & 0 \\
\hline
\end{tabular}

at the interfaces. Increasing the hydrocarbon content in the surfactant molecules increases their hydrophobicity; hence the molecules will tend to form micelles, which will decrease their biological activities more than the more adsorbed surfactant molecules (with shorter hydrocarbon chain lengths).

It is believed from recent studies on cationic surfactants that they have an excellent bactericidal activity [40], which depends on the hydrophobic chain length, activity and the dosage of this cationic. Table 4 revealed that the hydrophobic chain length of the cationic surfactants plays an important role in their biological activities against the targeted microorganisms. Several researchers have dealt with the mode of action of these types of compounds on different microorganisms [41]. The most likely explanation is through the surface adsorption mechanism, i.e., the adsorption of quaternary ammonium salt molecules on the outer cellular membrane of the microorganisms due to their amphipathic characteristics. In addition, the similarity between the hydrophobic chains and the lipid layers and the building units of the cell membranes and the monosaccharide in these compounds [42] facilitates that adsorption. The adsorption of these molecules at the cellular membranes reaches its maximum extent at a higher dose, leading to a complete coverage of the membrane by the surfactant molecules, which are able to penetrate it. Furthermore, the positive charges in the cationic molecules neutralize the negative charges on the bacterial cell membranes.
Accordingly, the selective permeability which characterizes the outer cellular membrane is completely lost [43]. Hence, the vital transportation of essential components for cell bioreactions and activities is disturbed. This causes the death of these microorganisms [44]. The high adsorption tendency of these cationics increases their penetration through the cellular membrane, with a boost in activity.

Biocidal activity against sulfate-reducing bacteria (SRB)

The synthesized cationic Thiol polyurethane surfactants were evaluated for their biocidal action against sulfate-reducing bacterial (Desulfomonas pigra) (Table 5). Comparing the inhibition zone diameters of the tested Gram-positive, Gramnegative and D. pigra (Gram-negative) regarding the antibacterial activities of the synthesized biocides showed that their efficacies against sulfate reducing bacteria were found at considerably high values. However, these values are still lower than those of the other bacterial strains tested. This may be ascribed to the resistivity of the SRB bacterial strain to the aggressive environmental components due to the rigidity of their cellular membranes. The sulfate-reducing bacteria (as a potent type of Gram-negative bacteria) are characterized by a thick cellular membrane, so that these microorganisms have high resistance against bacterial biocides. Consequently, the creation of efficient antimicrobial agents against the Gram-negative bacteria is considered a promising step in the biocidal field [45]. 
TABLE 5. Antimicrobial activity of the cationic Thiol polyurethane surfactants against sulfate reducing bacteria.

\begin{tabular}{cc}
\hline Compounds & $\begin{array}{c}\text { Desulfomonas pigra (SRB) inhibition } \\
\text { zone diameter (mm/mg sample) }\end{array}$ \\
\hline Standard: tetracycline antibacterial agent & $\mathbf{2 5}$ \\
\hline $\mathrm{PQ}_{10}$ & 9 \\
\hline $\mathrm{PQ}_{12}$ & 12 \\
\hline $\mathrm{PQ}_{14}$ & 14 \\
\hline $\mathrm{PQ}_{16}$ & 11 \\
\hline $\mathrm{PQ}_{18}$ & 13 \\
\hline $\mathrm{PQ}_{20}$ & 15 \\
\hline
\end{tabular}

\section{Corrosion inhibition efficiency}

The inhibiting efficiencies (IE \%) of the synthesized cationic surfactants towards the corrosion of carbon steel in $2 \mathrm{~N} \mathrm{H}_{2} \mathrm{SO}_{4}$ were measured at $25^{\circ} \mathrm{C}$ using the weight loss technique at different concentrations of the surfactants $(50$, 100, 200, 400 and 600 ppm).

Inhibition efficiency of the cationic Thiol polyurethane surfactants has higher values than the most other cationic surfactants reported elsewhere at inhibitor dose (600 ppm). Values of inhibition efficiency ranged between $92.12 \%-97.73 \%$. This is attributed to the presence of Thiol group and urethane group in the compounds which allow an adsorption on the metal surface. The adsorption of cationic Thiol polyurethane surfactants on the carbon steel surface in $2 \mathrm{~N} \mathrm{H}_{2} \mathrm{SO}_{4}$ solution occurs through the active centers in the inhibitors molecule which contain electronegative of $\mathrm{SH}$, lone pair of $\mathrm{N}$, double bond (urethane group) and $\pi$ electrons of aromatic ring which they can easily adsorb on the metal surface and then reduce the dissolution of carbon steel.

It has been observed that the adsorption of these inhibitors depends on the physicochemical properties of the functional groups and the electron density at the donor atom. The adsorption occurs due to the interaction of the lone pair and/ or p-orbitals of inhibitor with d-orbitals of the metal surface atoms, leading to the formation of a corrosion protection film.

The inhibition efficiencies of the tested inhibitors depend on inhibitor dose and hydrophobic chain length.

Inhibitor dose

Values obtained from weight loss measurements are summarized in Table 6 for the inhibitors (PQ10 - PQ20). It was found that, the gradual increase of the inhibitor dose (from 50 to $600 \mathrm{ppm}$ ) gradually increases the corresponding inhibition efficiency. This could be attributed to the adsorption of the inhibitor molecules onto the metal surface [46]. The adsorbed inhibitor molecules form a protective layer at the metal surface, which prevents the metal-aggressive medium contact. Increasing the inhibitor dose increases the amount of the adsorbed molecules at the metal surface [47]. Consequently, thick and compact adsorbed layer is formed, which increases the inhibition efficiency considerably. It is clear, as the dose reached $600 \mathrm{ppm}$; IE\% reached a high value of $97.73 \%$ for $\mathrm{PQ} 14$ at $25^{\circ} \mathrm{C}$, which represented excellent inhibition value.

Surface coverage values were calculated from the corrosion rate data according to Eq. (3):

$$
\Theta=\left[\left(R_{0}-R\right) / R_{0}\right]
$$

$\mathrm{R}_{0}$ is the corrosion rate in the absence of inhibitors; $\mathrm{R}$ is the corrosion rate in the presence of inhibitors.

The correlation between the inhibitor dose and the percent of metal surface covered by the inhibitor molecules $(\Theta)$ is called the adsorption isotherm and provides information about the interaction between the inhibitor molecules and the metal surface [48]. The correlation between $\Theta$ and the inhibitor concentration in the corrosive medium was represented by Langmuir adsorption isotherm, which is numerically represented in Eq. (4) [49]:

$$
\Theta /(1 / \Theta)=\mathrm{K}_{\text {ads }} \mathrm{C}
$$

where $\mathrm{K}_{\text {ads }}$ is the equilibrium constant of the 
TABLE 6. Data obtained from weight loss measurements for carbon steel dissolution in $2 \mathrm{~N}_{2} \mathrm{H}_{2} \mathrm{SO}_{4}$ solution in absence and presence of various inhibitor concentrations at $25^{\circ} \mathrm{C}$.

\begin{tabular}{|c|c|c|c|c|}
\hline Inhibitor & Dose, (ppm) & $\begin{array}{c}\text { Corrosion rate, } \\
\left(\mathrm{mg} \mathrm{cm}^{-2} \text { day }^{-1}\right)\end{array}$ & $\begin{array}{c}\text { Surface coverage, } \\
(\theta)\end{array}$ & $\begin{array}{l}\text { Corrosion inhibition } \\
\text { efficiency, (IE \%) }\end{array}$ \\
\hline $\begin{array}{c}2 \mathrm{~N} \mathrm{H}_{2} \mathrm{SO}_{4} \\
\text { (Without inhibitor) }\end{array}$ & -- & 29.47 & -- & -- \\
\hline \multirow[t]{5}{*}{ PQ10 } & 50 & 13.09 & 0.49 & 49.46 \\
\hline & 100 & 9.32 & 0.63 & 62.85 \\
\hline & 200 & 5.43 & 0.78 & 77.64 \\
\hline & 400 & 3.28 & 0.88 & 87.69 \\
\hline & 600 & 2.07 & 0.92 & 92.12 \\
\hline \multirow[t]{5}{*}{ PQ12 } & 50 & 13.73 & 0.47 & 47.08 \\
\hline & 100 & 9.77 & 0.60 & 60.37 \\
\hline & 200 & 5.62 & 0.75 & 75.48 \\
\hline & 400 & 2.57 & 0.89 & 89.20 \\
\hline & 600 & 1.77 & 0.93 & 92.66 \\
\hline \multirow[t]{5}{*}{ PQ14 } & 50 & 3.69 & 0.81 & 81.10 \\
\hline & 100 & 3.02 & 0.86 & 85.96 \\
\hline & 200 & 1.28 & 0.94 & 94.06 \\
\hline & 400 & 0.68 & 0.97 & 97.30 \\
\hline & 600 & 0.64 & 0.98 & 97.73 \\
\hline \multirow[t]{5}{*}{ PQ16 } & 50 & 11.96 & 0.53 & 53.56 \\
\hline & 100 & 9.62 & 0.62 & 61.99 \\
\hline & 200 & 4.90 & 0.77 & 77.54 \\
\hline & 400 & 2.68 & 0.87 & 86.93 \\
\hline & 600 & 0.75 & 0.96 & 96.33 \\
\hline \multirow[t]{5}{*}{ PQ18 } & 50 & 12.98 & 0.48 & 47.73 \\
\hline & 100 & 9.89 & 0.57 & 57.45 \\
\hline & 200 & 6.34 & 0.70 & 70.30 \\
\hline & 400 & 2.11 & 0.88 & 87.80 \\
\hline & 600 & 1.21 & 0.94 & 94.17 \\
\hline \multirow[t]{5}{*}{ PQ20 } & 50 & 9.36 & 0.60 & 60.04 \\
\hline & 100 & 7.24 & 0.69 & 68.79 \\
\hline & 200 & 3.73 & 0.82 & 81.96 \\
\hline & 400 & 3.62 & 0.83 & 83.04 \\
\hline & 600 & 0.75 & 0.96 & 96.33 \\
\hline
\end{tabular}

Egypt. J. Chem. 61, No. 1 (2018) 
inhibitor adsorption process and $\mathrm{C}$ is the molar concentration of the inhibitor. This model suggests that the inhibitor molecules occupy only one site on the metal surface and there is no interaction between the other adsorbed molecules [48]. The plot between $\mathrm{C} / \boldsymbol{\theta}$ and $\mathrm{C}$ gave a straight line (Fig.3), which suggests that the adsorption of the inhibitor molecules on the metal surface obeyed the Langmuir adsorption model [50]. The values of the linear regression coefficient (r) slope and adsorption coefficients of the different inhibitors are listed in Table 7. The correlation coefficient values $(r \geq 0.9978)$ indicate that the inhibition of the carbon steel by cationic Thiol polyurethane derivatives (PQ10-PQ20) was attributed to the adsorption of the inhibitor molecules on the metal surface. The adsorption isotherm slopes are close to unity, which indicates that there is no interaction between the adsorbed inhibitor molecules at the metal interface.

The intercept of Langmuir adsorption isotherm $\left(\mathrm{K}_{\text {ads }}\right)$ is related to the adsorption free energy of inhibitor molecules onto the metal surface, $\Delta \mathrm{G}_{\mathrm{ads}}$, according to Eq. (5) [47]:

$$
\Delta \mathrm{G}_{\mathrm{ads}}=-\mathrm{RT} \operatorname{Ln}\left(55.5 \mathrm{~K}_{\mathrm{ads}}\right)
$$

The value and sign of $\Delta \mathrm{G}_{\text {ads }}$ provide more information about the mechanism of the inhibitor molecules adsorption at the metal surface. The negative values of $\Delta \mathrm{G}_{\mathrm{ads}}$ indicate that the inhibitor molecules adsorbed spontaneously onto the metal surface $[46,47]$. On the other hand, the $\Delta G_{\text {ads }}$ values describe the type of inhibitor molecule adsorption on the metal surface.
Generally, the magnitude of $\Delta \mathrm{G}_{\mathrm{ads}}$ is around - $20 \mathrm{~kJ} / \mathrm{mol}$ or lower are consistent with the electrostatic interaction between charged inhibitor molecules and the charged metal surface (physisorption); those around - $40 \mathrm{~kJ} / \mathrm{mol}$ or higher involve charge sharing or transfer from the inhibitor molecules to the metal surface to form a coordinate type of bond (chemisorption) [5155]. The $\Delta \mathrm{G}_{\text {ads }}$ values are ranged between -18.12 and $-26.49 \mathrm{~kJ} / \mathrm{mol}$. The obtained values of $\Delta \mathrm{G}_{\text {ads }}$ indicate that the adsorption takes place mainly through the electrostatic interaction between charged inhibitor molecules and the charged metal surface (physisorption and chemisorptions) [56].

\section{Hydrophobic chain length}

Figure 4 represents the effect of the hydrophobic chain length of the synthesized inhibitors on their inhibition efficiencies towards corrosion of carbon steel in $2 \mathrm{~N} \mathrm{H}_{2} \mathrm{SO}_{4}$ solution at $25^{\circ} \mathrm{C}$. It is clear that the gradual increase in the hydrophobic chain length from 8-18 methylene group increases the inhibition efficiency of the cationic inhibitors. The longest hydrophobic chain length of PQ20 can inhibit the corrosion of carbon steel in $2 \mathrm{~N} \mathrm{H}_{2} \mathrm{SO}_{4}$ at 96.3 in presence of $600 \mathrm{ppm}$. The surface parameters in Table 3 reveal that inhibitors containing longer hydrophobic chains exhibit more surface activity and display great ability towards adsorption at the interfaces. Increasing the adsorption tendency of the inhibitor molecules increases their accumulation onto the metal interface [47]. This is suggested from the values of the surface coverage at the metal surface, Table 7. Thereby, the inhibitor molecules form condense adsorbed layer on the metal surface,

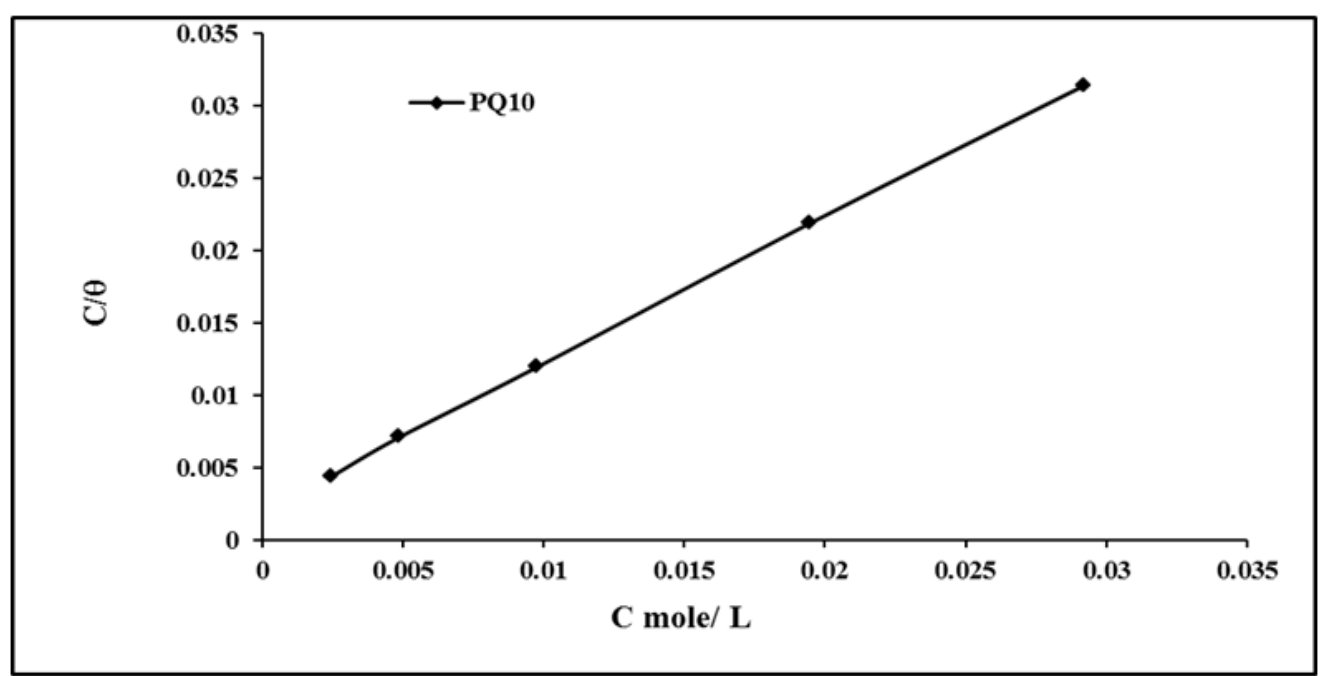

Fig. 3. Langmuir adsorption isotherm of $\mathrm{PQ10}$ inhibitor in $2 \mathrm{~N} \mathrm{H}_{2} \mathrm{SO}_{4}$ medium at $25^{\circ} \mathrm{C}$. Data are mean of three replicates withrelative error $\approx 5 \%$. 


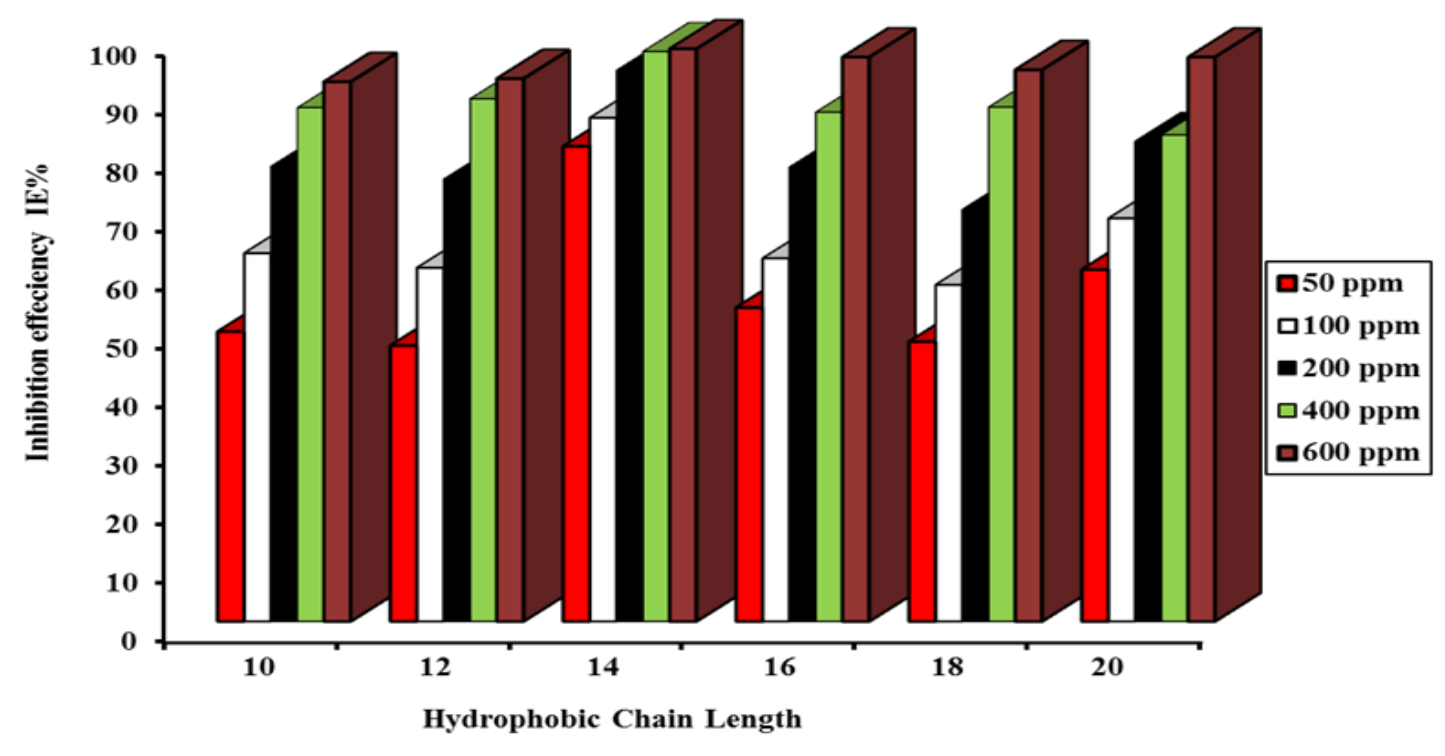

Fig. 4. Effect of the hydrophobic chain length on the inhibition efficiency (IE\%) of PQ10-PQ20 inhibitors in $2 \mathrm{~N}$ $\mathrm{H}_{2} \mathrm{SO}_{4}$ at $25^{\circ} \mathrm{C}$.

Data are mean of three replicates with relative error $\approx 5 \%$.

TABLE 7. Thermodynamic parameters for the adsorption of PQ10-PQ20 inhibitors on carbon steel surface in $2 \mathrm{~N}$ $\mathrm{H}_{2} \mathrm{SO}_{4}$ at $25^{\circ} \mathrm{C}$.

\begin{tabular}{lccccc}
\hline \multicolumn{1}{c}{ Inhibitor } & $\begin{array}{c}\text { Surface coverage } \\
\Theta\end{array}$ & Slope & $\begin{array}{c}\text { Linear regression } \\
\text { coeffecient }\end{array}$ & $\mathbf{K}_{\text {ads }}$ & $\Delta \mathbf{G}_{\text {ads }}(\mathbf{k j} / \mathbf{m o l e})$ \\
\hline PQ10 & 0.92 & 1.008152 & 0.9999 & 476.19 & -25.22 \\
PQ12 & 0.94 & 0.982213 & 0.9999 & 446.43 & -25.07 \\
PQ14 & 0.97 & 1.0071 & 0.9999 & 270.03 & -18.12 \\
PQ16 & 0.97 & 0.960824 & 0.9992 & 502.51 & -25.36 \\
PQ18 & 0.96 & 0.958644 & 0.9993 & 469.48 & -25.19 \\
PQ20 & 0.97 & 0.999035 & 0.9978 & 793.65 & -26.49
\end{tabular}

The data with a relative error of $\approx 5 \%$. q: Degree of surface coverage by inhibitor molecules at $600 \mathrm{ppm}, \mathrm{K}_{\text {ads }}$ : equilibrium constant for the adsorption process of inhibitor molecules, $\Delta \mathrm{G}_{\mathrm{ads}}$ : the adsorption free energy of inhibitor molecules onto the metal surface.

which prevents the reaction between the acidic medium and the metal; hence, the inhibition efficiency increases [57-58].

\section{Conclusions}

The main conclusions of the study may be presented in the following points:

1. The synthesized surfactants showed good Egypt. J. Chem. 61, No. 1 (2018) surface activity including effectiveness and CMC and also good ability towards adsorption at the interface.

2. The antimicrobial activities of the compounds towards bacteria and fungi were (moderatehigh) compared to the blanks used.

3. The compounds showed high inhibition 
efficiency for the corrosion of carbon steel in $2 \mathrm{~N} \mathrm{H} 2 \mathrm{SO} 4$ at $25{ }^{\circ} \mathrm{C}$ at higher doses (400ppm and $600 \mathrm{ppm}$ ).

4. The adsorption of the synthesized cationic surfactant on the carbon steel surface represented a mixture of chemical and physical adsorption, it also obeyed Langmuir isotherm.

5. The antimicrobial activity and corrosion inhibition efficiencies depended on the chemical structure of the synthesized surfactants.

\section{References}

1. Finsgar M. and Jackson J., Application of corrosion inhibitors for steels in acidic media for the oil and gas industry: A review. Corrosion Science 86, 17-41 (2014).

2. Amin M. A., Abd El-Rehim S. S., El-Sherbini E. F. and Bayoumi R. S., The inhibition of low carbon steel corrosion in hydrochloric acid solutions by succinic acid Part I. Weight loss, polarization, EIS, PZC, EDX and SEM studies. Electrochim. Acta, 52, 3588-594 (2007)

3. Okafor P. C. and Zheng Y. G., Synergistic inhibition behavior of methylbenzyl quaternary imidazoline derivative and iodide ions on mild steel in $\mathrm{H} 2 \mathrm{SO} 4$ solutions. Corros. Sci., 51, 850-859 (2009).

4. Okafor P. C., Liu, X. and Zheng, Y. G., Corrosion inhibition of mild steel by ethylamino imidazoline derivative in CO2- saturated solution. Corros. Sci., 51, 761-768 (2009).

5. Yi H. Yanqiu Z., Ranran Y., Lan M., and Zhao C., Imidazoline derivative with four imidazole reaction centers as an effi cient corrosion inhibitor for Anti-CO2 corrosion. Russian Journal of Applied Chemistry, 88, 1192-1200 (2015).

6. Quraishi, M. A. and Sardar, R., Inhibition of mild steel corrosion in the presence of fatty acid triazoles. J. Appl. Electrochem., 32,425-432 (2002)

7. Fouda A. S., Shalabi K. and Mohamed N. H., Corrosion inhibition of aluminum in hydrochloric acid solutions using some chalcone derivatives. International Journal of Innovative Research in Science, Engineering and Technology, 3, 9861-9875 (2014).

8. Arukalam,I. O., Madu I. O., Ijomah N. T., Ewulonu C. M. and Onyeagoro G. N., Acid corrosion inhibition and adsorption behaviour of ethyl hydroxyethyl cellulose on mild steel corrosion. Journal of materials, DOI. 10.1155/2014/101709 (2014).

9. Ben Hmamou, D., Salghi R., Zarrouk, A. Messali M., Zarrok H., Errami M., Hammouti B., Bazzi L. and Chakir A., Inhibition of steel corrosion in hydrochloric acid solution by chamomile extract. Scholars Research Library, 4, 1496-1505 (2012).

10. Umoren S.A., Eduok U.M. and Oguzie E.E., Corrosion inhibition of mild steel in $1 \mathrm{M} \mathrm{H} 2 \mathrm{SO} 4$ by polyvinyl pyrrolidone and synergistic iodide additives. Portugaliae Electrochimica Acta 26, 533-546 (2008).

11. Emregul K.C. and Atakol O., Corrosion inhibition of mild steel with Schiff base compounds in $1 \mathrm{M}$ HCl. Mater. Chem. Phys., 82, 188-193 (2003).

12. Walker M.L., Corrosion Inhibitor. Canadian Patent No. CA. 2,482,513. (2004).

13. Ono D., Yamamura S., Nakamura M., and Takeda T., preparation and properties of bis (sodium sulfate) types of cleavable surfactants derived from diethyl titrate. Journal of Oleo Science, 54, 51-57 (2005).

14. Qiu L. G., Xie A. J. and Shen Y. H., Understanding the effect of the spacer length on adsorption of gemini surfactants onto steel surface in acid medium. Appl. Surf. Sci. 246, 1-9 (2005).

15. Qiu L. G., Xie A. J. and Shen Y. H., A novel triazole based cationic gemini surfactant: synthesis and effect on corrosion inhibition of carbon steel in hydrochloric acid. Mater. Chem. Phys., 91, 269-275 (2005).

16. Qiu L. G., Xie A. J. and Shen Y. H., The adsorption and corrosion inhibition of some cationic gemini surfactants on carbon steel surface in hydrochloric acid. Corros. Sci., 47, 273-278 (2005).

17. Zhu W.R., Hu P.Z., Li M.Y., Huang X.L. and Wu C.T., Synthesis of new Schiff bases containing thiophene moiety. J. Nat Sci. 8, 433-436 (2003).

18. Li M.Y., Hu P.Z., Zhu W.R. and Wang Y., Synthesis and characterization of open ring polycomponent complexes formed in the reaction of lanthanide with m-phenylenediamine and dibenzoyl methane. Asian J. Chem. 15, 38-42 (2003).

Egypt. J. Chem. 61, No. 1 (2018) 
19. Anionic Gemini Surfactant: Synthesis, SurfaceActive Properties and Antimicrobial Study. J Surfact Deterg, DOI 10.1007/s11743-017-1977-1 (2017).

20. Carroy A., Hintermann T., Baudin G., Bauer, D., Contich P., Dietliker K., Faller M., Steck R. K., Lordelot C. and Misteli K., Novel latent catalyst for 2K-PUR systems, Prog. Org. Coat. 68, 37-41 (2010).

21. Negm N. A., El-Farargy A. F., Zaki M. F., Mahmoud S. A. and Abdel Rahman N. R., Cationic Schiff base amphiphiles: 1. synthesis, characterization and surface activities of cationic surfactants bearing Schiff base groups and their $\mathrm{Mn}(\mathrm{II}), \mathrm{Cu}(\mathrm{II})$ and Co(II) complexes. Egypt J. Petrol 17, 15-25 (2008).

22. Zaky M. F., Badawi A. M., Sabbah I. A., Abdelghani R. A. and Hendawy M. E., Synthesis, characterization and surface activities of cationic polysaccharide (Aloe) schiff base surfactants. $J$. Surfact Deterg 18, 455-461 (2015).

23. Rosen M. J., Surfactants And Interfacial Phenomena, $2^{\text {nd }}$ edn. Wiley, New York (1989).

24. Hany, M. A., Ahmed H. T. and Antar A. A., Novel quaternary ammonium-based cationic surfactants: Synthesis, surface activity and evaluation as corrosion inhibitors for $\mathrm{C} 1018$ carbon steel in acidic chloride solution. J. Surfact Deterg, 20, 735753 (2017).

25. National Committee for Clinical Laboratory Standards., Methods for dilution antimicrobial susceptibility tests for bacteria that grow aerobically. Approved standard M7-A4. National Committee for Clinical Laboratory standards, Wayne, (1997).

26. Negm N. A., Aiad I. A. and Tawfik S. M., Screening for potential antimicrobial activities of some cationic uracil biocides against wide spreading bacterial strains. J. Surf. Deterg., 13, 503-511 (2010)

27. ASTM G1-72. Practice for preparing, cleaning and evaluating corrosion test specimens, (1990).

28. Bhupendra, M. M., Niketan, S. P., Mayank, J. P. and Smita, J., (2011) Corrosion inhibition performance of 1,3,5-triazinyl urea derivatives as a corrosion inhibitor for mild steel in $1 \mathrm{~N} \mathrm{HCL}$. Res Chem Intermed 37, 659-671 (2011).

29. Lehr, I. L. and Saidman, S. B., Characterization Egypt. J. Chem. 61, No. 1 (2018) and corrosion protection properties of polypyrrole electropolymerized onto aluminum in the presence of molybdate and nitrate. Electrochim. Acta., 51, 3249-3255 (2006).

30. Negm N.A. and Aiad I., Synthesis and Characterization of multifunctional surfactants in oil-field protection applications. J. Surf. Deterg., 8, 87-92 (2007).

31. Negm N. A., Zaki M. F. and Salem M. A. I., Synthesis and evaluation of 4-diethyl amino benzaldehyde schiff base cationic amphiphiles as corrosion inhibitors for carbon steel in different acidic media. J. Dispers Sci. Technol. 12, 321-329 (2010).

32. Hafiz A. A., Badawi A. M., El-Deeb F. I., Soliman E. A. and El-Awady M. Y., Ferrocene-based cationic surfactants: surface and antimicrobial properties. $J$. Surfactant Deterg. 13, 165-172 (2010).

33. Kuperkar K., Modi J. and Patel K., Surface-active properties and antimicrobial study of conventional cationic and synthesized symmetrical Gemini surfactants. J. Surfactants Deterg. 15, 107-115 (2012).

34. Perez L., Pinazo A., Pons R. and Infante M., Gemini surfactants from natural amino acids. Adv. Coll Interface Sci., 205,134-155. (2014).

35. Aiad I. A., Badawi A. M., El-Sukkary M.M., ElSawy A. A. and Adawy A. I., Synthesis and biocidal activity of some naphthalene-based cationic surfactants. J. Surfactants Deterg. 15, 223-234 (2012).

36. Yongbo S., Qiuxiao L., Yunling L. and Lifei Z., Biological behaviors of guanidine-based cationic surfactants. J. Surf Deterg 17, 459-464 (2014).

37. Ghumare A., Pawar B. and Bhagwat S., Synthesis and antibacterial activity of novel amido-aminebased cationic Gemini surfactants. J. Surf Deterg 16, 85-93 (2013).

38. Cornellas A., Perez L., Comelles F., Ribosa I., Manresa A. and Garcia M. T., Self-aggregation and antimicrobial activity of imidazolium and pyridinium based ionic liquids in aqueous solution. J. Colloid Interface. Sci. 355, 164-171 (2011).

39. Campanac C., Pineau L., Payard A., BaziardMouysset G. and Roques C., Interactions between biocide cationic agents and bacterial biofilms. 
Antimicrob Agents Chem. 46, 1469-1474 (2002).

40. Migahed M. A., Negm N. A., Shaban M. M., Ali T. A. and Fadda A. A., Synthesis, characterization, surface and biological activity of diquaternary cationic surfactants containing ester linkage. $J$ Surfact Deterg 19, 119-128 (2016)

41. Miyuki M., Takashi N. and Masahiko A., Interaction of guanidine-type surfactants with biological substances. J. Oleo Sci. 59, 101-108 (2010)

42. Chernomordik I., Kozlov M. M. and Zimmerberg, lipids in biological membrane fusion. $J$. of Membrane. Biology. 146, 1:14 (1995).

43. Saier M.H.J., Enzymes in Metabolic Pathways: A comparative study of mechanism, structure, evaluation and control. Harper and Row, New York, (1987).

44. Jack D.L., Yang N.M. and Saier M.H., The drug/ metabolite transporter superfamily. J. Eur. J. Biochem. 268, 3620 (2001)

45. Tawfik S.M., Sayed A. and Aiad I., Corrosion inhibition by some cationic surfactants in oil fields. J. Surfactants Deterg. 15, 577-585 (2012).

46. Negm, N. A., El Sabagh, A.M., Migahed, M.A., Abdel Bary, H. M. and El Din, H. M., Effectiveness of some diquaternary ammonium surfactants as corrosion inhibitors for carbon steel in $0.5 \mathrm{M} \mathrm{HCl}$ solution. Corros. Sci., 52, 2122-2132 (2010).

47. Elkholy, Y. M., Zahran, M. K. and Tawfik, S.M., Corrosion inhibition efficiency and surface activity of benzothiazol-3-ium cationic Schiff base derivatives in hydrochloric acid. Corros. Sci., 52, 3536-4523 (2010).

48. Ansari, F. A. and Quraishi, M. A., Inhibitive effect of some gemini surfactants as corrosion inhibitors for mild steel in acetic acid media. Arab J. Sci. Eng. 36, 11-20 (2011).

49. Salah M. Tawfik, S. M. and Negm, N. A., Vanillinderived non-ionic surfactants as green corrosion inhibitors for carbon steel in acidic environments. Res. Chem Intermed 42, 3579-3607 (2016).
50. Adawy A. I., Abbas M. A., and Zakaria K., New Schiff base cationic surfactants as corrosion inhibitors for carbon steel in acidic medium: weight loss, electrochemical and SEM characterization techniques. Res Chem Intermed 42, 3385-3411 (2016).

51. Tawfik S.M., Ali A. A. and Aiad I., Three gemini cationic surfactants as biodegradable corrosion inhibitors for carbon steel in $\mathrm{HCl}$ solution. Res Chem. Intermed 42, 1101-1123 (2016).

52. Herrag L., Hammouti B., Elkadiri S., Aouniti A., Jama C., Vezin H. and Bentiss F., Adsorption properties and inhibition of mild steel corrosion in hydrochloric solution by some newly synthesized diamine derivatives: experimental and theoretical investigations. Corros Sci. 52, 3042-3051 (2010).

53. Solmaz R., Investigation of adsorption and corrosion inhibition of mild steel in hydrochloric acid solution by 5-(4- dimethylaminobenzylidene) rhodanine. Corros Sci. 79, 169-176 (2014).

54. Hegazy M.A., Abd El-Rehim S.S., Badr E. A., Kamel W. M. and Youssif A. H., Mono-, di- and tetra-cationic surfactants as carbon steel corrosion inhibitors. J. Surfact Deterg 18, 1033-1042 (2015).

55. Mehdaoui R., Khelifa A. and Aaboubi O., Inhibiting effect of some synthesized surfactants from petroleum oils on the corrosion of aluminium in hydrochloric acid solution. Res. Chem. Intermed 41, 705-720 (2015).

56. Sobhi M., El-sayed R. and Abdallah M., The effect of non ionic surfactants containing triazole, thiadiazole and oxadiazole as inhibitors of the corrosion of carbon steel in 1M hydrochloric acid. J. Surfact Deterg 16, 937-946 (2013).

57. Mobin M., Parveen M., and Rafiquee M.Z.A., Inhibition of mild steel corrosion using 1-histidine and synergistic surfactants additives. Journal of Materials Engineering and Performance 22, 548 -556 (2013).

58. Manuel E.P., Crescencio O.O., Natalya V.L. and Jonathan-Boanerge P.N., Imidazolium, pyridinium and dimethyl-ethylbenzyl ammonium derived compounds as mixed corrosion inhibitors in acidic medium. Surfact Deterg 14, 211-220 (2011).

(Received 19/11/2017; accepted 19/12/2017)

Egypt. J. Chem. 61, No. 1 (2018) 
من البولي يوريثان ثيويةل وتثيط التآكل لبعض المواد ذات النشاط السطحي الكاتيونية المشتقة

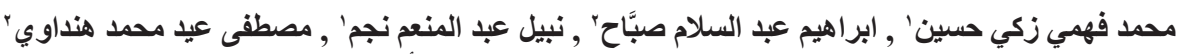

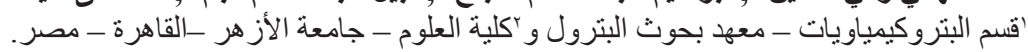

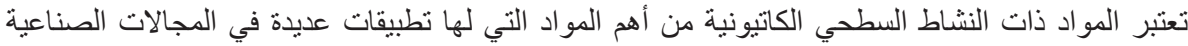

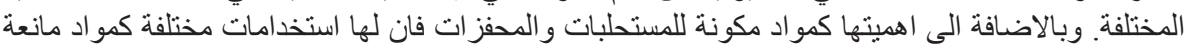
لنمو البكتيريا و الفطريات ومو اد مانعة أو مثبطة للتآكل. في هذا العمل:

تم تحضير ستة مو اد ذات نثاط سطحي كاتيونية مشتقة من البولي يوريثان ثيول:

وذللك عن طريق تفاعل ستة استرات تم تحضير ها من تفاعل البرومو اسيتيك اسيد مع ستة كحو لات دهنية التئية

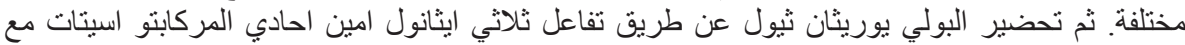

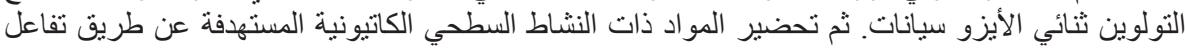
البولي يوريثان ثيول مع استرات الكحو لات الدهنية الدختلفة.

تم اثبات التركيب الكيميائي للمواد المحضرة باستخدام التحاليل الكمية العنصرية وطيف الأشعة تحت الحمراء والرنين النووي المغناطيسي لذرات الهيدروجين وطيف الأشعة فوق البنفسجية.

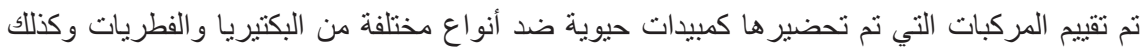

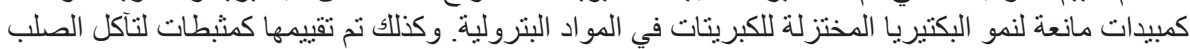
الكربوني في الوسط الحامضي باستخدام طريقة الفقد في الوزن. 